\title{
Physiological and morphological characteristics of Phaseolus vulgaris L. grown in soil with picloram residues ${ }^{1}$
}

\author{
Miguel Henrique Rosa Franco ${ }^{2}$, Vinícius Teixeira Lemos ${ }^{3}$, André Cabral França², Nykolas Carvalho Schiavon², \\ Marco Túlio Gomes Albuquerque 2 , Ademílson de Oliveira Alecrim³ ${ }^{3}$ Leonardo D’Antonino ${ }^{4}$
}

\section{ABSTRACT}

The long lasting residual effect of some auxin herbicides depends on soil characteristics and may cause phytotoxicity on subsequent crops. Picloram is one of the main herbicides used in pastures, presenting a long lasting residual effect in the soil. This study aimed at determining the physiological and morphological characteristics of common bean plants grown in soil contaminated with picloram, under greenhouse conditions. A complete randomized blocks design, with treatments consisting of picloram doses $\left(0 \mathrm{~g} \mathrm{ha}^{-1}, 7.5 \mathrm{~g} \mathrm{ha}^{-1}, 15 \mathrm{~g} \mathrm{ha}^{-1}\right.$, $30 \mathrm{~g} \mathrm{ha}^{-1}, 60 \mathrm{~g} \mathrm{ha}^{-1}$ and $120 \mathrm{~g} \mathrm{ha}^{-1}$ a.i.), with five replications, was used. Urochloa brizantha was sown in pots, and its height and shoot fresh and dry matter were evaluated. In the same pots, Phaseolus vulgaris was sown as a bio-indicator of picloram, and the following characteristics were measured: plant height, fresh and dry matter, phytotoxicity, leaf area, number of leaves per plant, maximum photosynthetic efficiency and relative electron transport rate. The phytoremediation process occurs in soil with picloram residues (up to $30 \mathrm{~g} \mathrm{ha}^{-1}$ ) when covered by $U$. brizantha for 150 days. The common bean plants show a good potential as biological indicator of the presence of picloram residues in the soil.

KEY-WORDS: Urochloa brizantha; auxin herbicides; soil contamination; phytoremediation.

\section{INTRODUCTION}

Brazil has recently become the largest consumer market of agrochemicals worldwide, and herbicides represent $45 \%$ of the total consumption of such chemicals (SINDAG 2009).

The increasing use of herbicides is a serious issue, due to its environmental contamination, especially in underground water (Celis et al. 2005). It is known that herbicides may negatively influence subsequent crops, due to its carryover effect, and

\section{RESUMO}

Características fisiológicas e morfológicas de Phaseolus vulgaris L. cultivado em solo com resíduos de picloram

A longa persistência de alguns herbicidas auxínicos depende dos atributos do solo e pode causar intoxicação em cultivos em sucessão. O picloram é um dos principais herbicidas utilizados em pastagens, sendo que o mesmo apresenta período de meiavida longo no solo. Objetivou-se avaliar, em casa-de-vegetação, as características fisiológicas e morfológicas de plantas de feijão cultivadas em solo contaminado com picloram. O delineamento utilizado foi em blocos ao acaso, sendo os tratamentos compostos pela aplicação de picloram ( $0 \mathrm{~g} \mathrm{ha}^{-1} ; 7,5 \mathrm{~g} \mathrm{ha}^{-1} ; 15 \mathrm{~g} \mathrm{ha}^{-1} ; 30 \mathrm{~g} \mathrm{ha}^{-1}$; $60 \mathrm{~g} \mathrm{ha}^{-1}$; e $120 \mathrm{~g} \mathrm{ha}^{-1}$ i.a.), com cinco repetições. Urochloa brizantha foi semeada em vasos, avaliando-se a sua altura e matéria fresca e seca da parte aérea. Nos mesmos vasos, semeou-se feijão (Phaseolus vulgaris), como bioindicador do picloram, sendo avaliados a altura das plantas, matéria fresca e seca, fitotoxicidade, área foliar, número de folhas por planta, eficiência fotossintética máxima e taxa relativa de transporte de elétrons. Resíduos de picloram no solo (até $30 \mathrm{~g} \mathrm{ha}^{-1}$ ) são fitorremediados pelo cultivo de U. brizantha por 150 dias. As plantas de feijão apresentam bom potencial como indicador biológico da presença de resíduos de picloram no solo.

PALAVRAS-CHAVE: Urochloa brizantha; herbicidas auxínicos; contaminação do solo; fitorremediação.

also reach groundwater through leaching and surface runoff (D'Antonino et al. 2009, Santos et al. 2010).

Knowledge on adsorption, desorption, lifetime and leaching of herbicides is essential to identify eventual consequences of herbicide use for the environmental safety (Wyk \& Reinhrdt 2001).

Soil characteristics such as $\mathrm{pH}$, mineralogy, organic matter and cation exchange capacity (at $\mathrm{pH} 7.0$ ) may have a strong influence on control mechanisms of ionic herbicide destination in the soil (Costa et al. 2000, Rocha et al. 2000, Albuquerque et al. 2001).

1. Manuscript received in Mar./2016 and accepted for publication in Sep./2016 (http://dx.doi.org/10.1590/1983-40632016v4640169).

2. Universidade Federal dos Vales do Jequitinhonha e Mucuri, Diamantina, MG, Brazil.E-mails: miguelmhrf@yahoo.com.br, cabralfranca@yahoo.com.br, nc_schiavon@yahoo.com.br, marco.t.albuquerque@monsanto.com.

3. Universidade Federal de Lavras, Lavras, MG, Brazil.E-mails: lemosvt@yahoo.com.br, ademilsonagronomia@gmail.com. 4. Universidade Federal de Viçosa, Viçosa, MG, Brazil.E-mail: leodantonino@gmail.com. 
In Brazilian pastures, picloram is one of the main herbicides used to control broadleaf weeds that present selective characteristics to Poacea species (Santos et al. 2006). This herbicide has an average activity period of 20 to 300 days (Berisford et al. 2006, Santos et al. 2006) and, in some cases, may remain in the soil for 3 years after its application (Deubert \& Corte-Real 1986, Santos et al. 2006).

Picloram is an auxinic herbicide, i.e., that mimics auxin. Auxinic herbicides were introduced in agriculture in the 1940s, and were the first selective organic herbicides for weed control. They are still extensively used in rice, maize, wheat, sugarcane and pastures (Thill 2003).

Among this group of herbicides, 2.4-D (2.4-dichlorophenoxyacetic acid) and picloram (4-amino-3.5.6-trichloro-2-pyridinecarboxylic acid) have the largest number of auxinic products registered for use in agriculture (Brasil 2013). These products are latifolicide mixtures. According to Silva et al. (2007), the 2.4-D herbicides cause poisoning in sensitive species such as soy, common bean, cotton and other dicots, when grown in areas where they are applied.

Given the risk of crop phytotoxicity, it is important to remove this herbicide using simple, effective and economically viable techniques (Pires et al. 2003). The phytoremediation potential of some Poacea species can be explored to accelerate the degradation or immobilization of some toxic herbicide components in the environment. It is known that the association of plants with microbes may accelerate degradation of toxic molecules, reducing the soil contamination (Cunningham et al. 1996).

The effectiveness of the method and the time required for remediation are directly related to the appropriate species selection for each type of toxic molecule, as well as soil and climatic condition (Santos et al. 2007a and 2007b).

Some plant species have been studied for their picloram phytoremediation potential in soil and for reducing its residual activity. Various forage species, such as Eleusine coracana, brachiaria and Panicum maximum, have been used in picloram phytoremediation programs (Santos et al. 2006 and 2007b, Belo et al. 2007a and 2007b, Carmo et al. 2008a and 2008b, Pires et al. 2008). Santos et al. (2013) studied the sensitivity of three species (beet, cucumber and tomato) for $2.4 \mathrm{D}$ and picloram to be used as indicators and concluded that beet and tomato are more sensitive, and the symptoms of visual intoxication ranged for assessing the presence of herbicide residues.

Various indicators are used to evaluate the toxic residual effects of herbicides in the soil. Photosynthesis characteristics, such as the measurement of chlorophyll fluorescence, specifically initial fluorescence (F0), maximum fluorescence $(\mathrm{Fm})$, variable fluorescence $(\mathrm{Fv})$, maximum quantum yield of PSII $(\mathrm{Fv} / \mathrm{Fm})$ and relative electron transport rate (ETR), are the main indicators used for such purpose (Krause \& Weis 1991, Franco et al. 2014).

Franco et al. (2014) concluded that Urochloa brizantha (Stapf) Webster (syn. Brachiaria brizantha Stapf), Piatã cultivar, acts effectively in the phytoremediation of soils contaminated with picloram. The longer the $U$. brizantha cultivation period, the greater is its phytoremediation potential. They also observed a recovery in the photosynthetic apparatus of common bean (Phaseolus vulgaris L.) as a bioindicator, after 240 days of Urochloa brizantha cultivation.

This study aimed at determining the physiological and morphological characteristics of common bean plants grown in soil contaminated with picloram.

\section{MATERIAL AND METHODS}

The experiment was conducted from June 2014 to June 2015, under greenhouse conditions, at the Universidade Federal dos Vales do Jequitinhonha e Mucuri, in Diamantina, Minas Gerais State, Brazil, using a complete randomized blocks design, with six treatments and five replications. The treatments consisted of picloram doses $\left(0 \mathrm{~g} \mathrm{ha}^{-1}, 7.5 \mathrm{~g} \mathrm{ha}^{-1}\right.$, $15 \mathrm{~g} \mathrm{ha}^{-1}, 30 \mathrm{~g} \mathrm{ha}^{-1}, 60 \mathrm{~g} \mathrm{ha}^{-1}$ and $120 \mathrm{~g} \mathrm{ha}^{-1}$ a.i.), using the commercial product Padron ${ }^{\circledR}$ (equivalent of $240 \mathrm{~g} \mathrm{~L}^{-1}$ of picloram acid, i.e., $0.0 \%, 3.12 \%$, $6.24 \%, 12.5 \%, 25.0 \%$ and $50.0 \%$ of Padron) in the soil. Subsequently, Urochloa brizantha (Piatã cultivar) was grown for phytoremediation.

A Red-Yellow Ultisol was used (Table 1). Soil samples were taken at the 0.0-0.20 m depth layer, in areas without herbicide application history, and sieved (4 mm mesh).

Dolomitic limestone was used as a corrective, according to the soil analysis, and the same was mixed 3 months prior to reaction. The soil was moistened every 15 days (Cantarutti et al. 1999). 
Table 1. Physical and chemical characteristics of the Red-Yellow Ultisol used in the experiment.

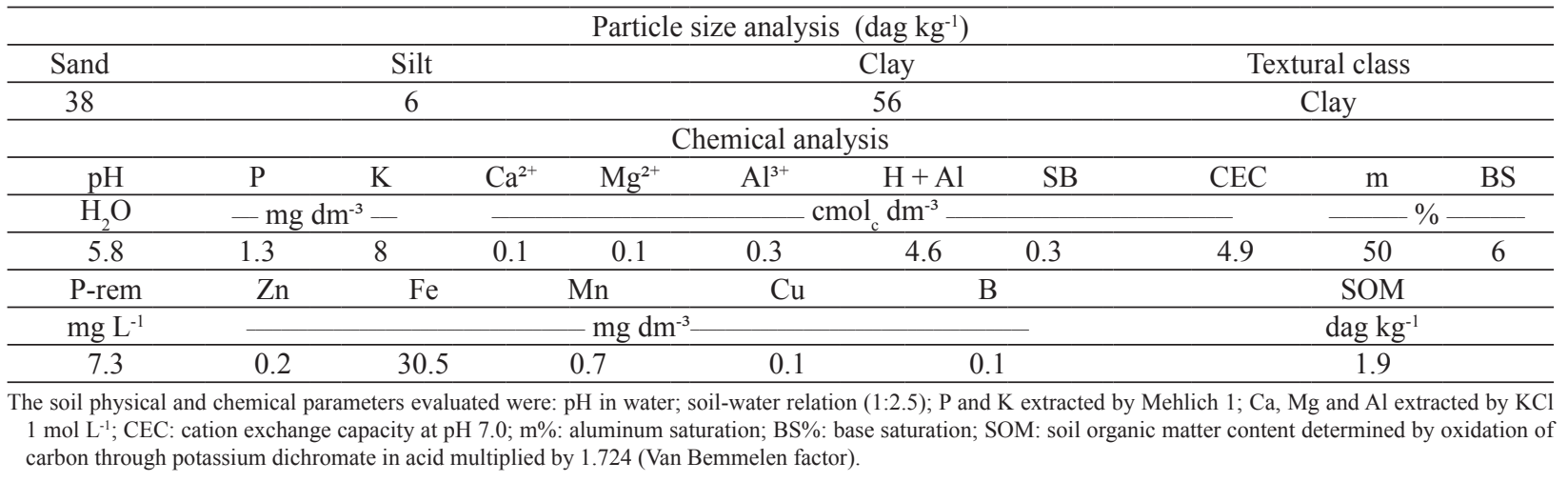

Fertilization was carried out by mixing NPK formulations before sowing. NPK sources were superphosphate, urea and potassium chloride. The fertilizers were mixed in soil over a canvas, using a hoe, and then the pots were filled following recommendations by Cantarutti et al. (1999).

The pots were covered with polyethylene film, in order to avoid herbicide loss through leaching. A total of $17 \mathrm{~kg}$ of substrate were used per pot, and irrigated to adjust the moisture to approximately $80 \%$ of field capacity.

The pots were filled with substrates (soil already corrected with agricultural concealer) and arranged in rows, to receive the herbicide application by a $\mathrm{CO}_{2}$ pressurized backpack sprayer, with calibrated pressure of $40 \mathrm{lpf}$ and 11003 spray nozzles, resulting in a flow rate of $200 \mathrm{~L} \mathrm{ha}^{-1}$.

At 5 days after the application (DAA) of picloram in humid soil, phytoremediation species were sown, and thinning was done at 7 days after emergence (DAE), to maintain four plants per pot.

After 150 days of brachiaria sowing (DAS), cutting was done to evaluate the fresh and dry matter weight $(\mathrm{g})$ and plant height $(\mathrm{cm})$. Thereafter, the common bean Pérola cultivar was planted in the pots, on racks above the soil surface, maintaining 2 plants per pot. At weekly intervals, a total of $5 \mathrm{~g} \mathrm{~L}^{-1}$ of Sempre Verde ${ }^{\circledR}$ foliar fertilizer (15-15-20) was applied. After 50 days of common bean sowing, the following parameters were measured: fresh and dry weight $(\mathrm{g})$, shoot height $(\mathrm{cm})$, leaf area $\left(\mathrm{cm}^{2}\right)$, number of leaves per plant and fluorescence estimation.

At 25 and 50 days after the sowing of bean plants, visual evaluations of intoxication were carried out using a percentage score scale ranging from 0 to
100 , where 0 implies in the absence of any injuries and 100 the plant death (ALAM 1974).

Following the shoot measurement (using a graduated ruler), plants were weighted using an electronic balance with precision of $0.0001 \mathrm{~g}$, to determine the fresh weight. Then, they were packed in paper bags and sent to the laboratory for measurements of leaf area and dry weight, using a Digital Area Analyzer (DAA) (Ferreira et al. 2008). For dry weight estimation, the material was kept in a greenhouse, at $65^{\circ} \mathrm{C}$, with constant air circulation, until the material reached constant weight.

After 50 DAS, the maximum quantum yield of $\mathrm{PSII}(\mathrm{Fv} / \mathrm{Fm})$ and relative electron transport rate (ETR) were determined from the totally expanded young leaves, using a portable modulated photosynthesis yield analyzer MINI-PAM (Walz, Germany).

At the end of the experiment, the common bean plants were removed from the pots and soil samples were collected and subjected to chemical characterization, to compare soil characteristics before and after the study (Table 2). Soil samples were taken at the $0.0-0.15 \mathrm{~m}$ depth layer of pots for a representative composite sample for each treatment.

Data were subjected to analysis of variance, using the F test $(\mathrm{p}<0.05)$, and regression analysis. The regression analysis with the selected model was done based on its significance, biological phenomena and coefficient of determination. These regressions were determined using linear and quadratic models, with the Sigmaplot software, version 10.

\section{RESULTS AND DISCUSSION}

The analysis of variance for plant height and shoot fresh and dry weight of Urochloa brizantha, at 
150 DAS, showed no significant difference among the factors (Table 3). The application of picloram did not influence these variables, confirming the selectivity of this species to this herbicide on the applied doses, and making it viable for further studies.

The number of leaves per plant of common bean at 50 DAS was exponentially reduced (Figure 1a) with increasing picloram doses, while a minimum reduction of $50 \%$ (equation estimated average) was observed up to $30 \mathrm{~g} \mathrm{ha}^{-1}$. The leaf area analysis of common bean plants sown after the harvest of phytoremediation species (Figure 1b), at 50 DAS, showed a significant reduction with increased picloram doses in the soil, when compared to the standard treatment.

It is possible to infer the tendency of positive relationship between number of leaves and leaf area, with both variables being similarly affected by picloram. D'Antonino et al. (2012) observed a reduction in leaf area with the increase of herbicide doses, in soil with coffee seedlings grown with different $\mathrm{pH}$ and contaminated with picloram residues. Even after 150 days of the herbicide application in forage, it still caused significant reduction in the development of common bean plants.

The same tendency of exponential decrease was observed for fresh weight (Figure 1c), dry weight (Figure 1d) and plant height (Figure 2a) of common bean, with increasing doses of picloram. It was also observed that higher doses of picloram (120 $\left.\mathrm{g} \mathrm{ha}^{-1}\right)$ caused the death of bioindicator plants.

Carmo et al. (2008a) evaluated the growing period of Panicum maximum for phytoremediation of soil contaminated with picloram and observed an increase in plant height of soybean after 60 days of $P$. maximum growth with $80 \mathrm{~g} \mathrm{ha}^{-1}$ and $160 \mathrm{~g} \mathrm{ha}^{-1}$ of picloram. Procópio et al. (2008) evaluated the prior cultivation of Eleusine coracana, in three different densities, and noted that it significantly reduced the toxicity of soybean plants evaluated at $15 \mathrm{DAE}$, when the initial contamination level in the soil was $80 \mathrm{~g} \mathrm{ha}^{-1}$ or $160 \mathrm{~g} \mathrm{ha}^{-1}$ of picloram.

Franco et al. (2014) studied different periods $(150,210,240,270$ and 300 DAS) of Urochloa brizantha (Stapf) Webster (syn. Brachiaria brizantha Stapf) (Piatã cultivar) growth, after the application

Table 2. Physical and chemical characteristics of the Red-Yellow Ultisol used in the experiment, after phytoremediation of the picloram herbicide.

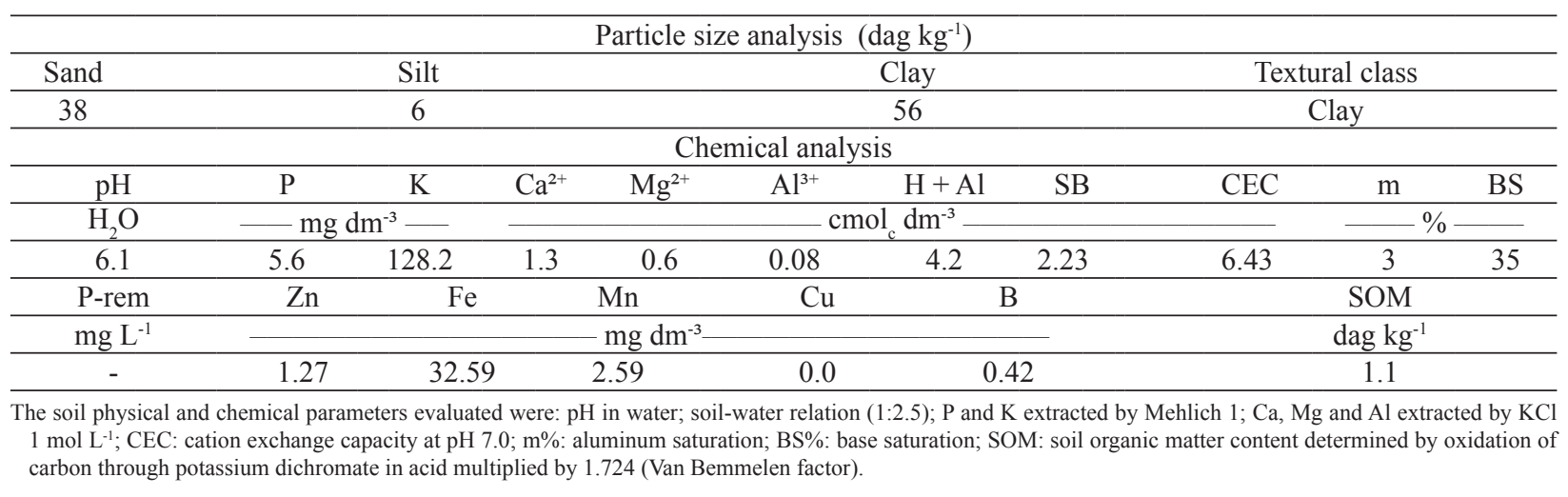

Table 3. Analysis of variance for plant height, shoot fresh and dry weight of Urochloa brizantha, at 150 DAS, after phytoremediation with picloram.

\begin{tabular}{lcccc}
\hline \multicolumn{1}{c}{$\begin{array}{c}\text { Source of } \\
\text { variation }\end{array}$} & $\begin{array}{c}\text { Degrees of } \\
\text { freedom }\end{array}$ & Plant height $(\mathrm{cm})$ & Mean square* & Dresh weight $(\mathrm{g})$ \\
\hline Treatments & 5 & $0.00173^{\mathrm{ns}}$ & $226.3315^{\mathrm{ns}}$ & $204.3267^{\mathrm{ns}}$ \\
Block & 4 & $0.02100^{\mathrm{ns}}$ & $1,616.2471^{\mathrm{ns}}$ & $393.6728^{\mathrm{ns}}$ \\
Residue & 20 & 0.01063 & 920.9553 & 187.2292 \\
\hline Mean & - & 1.25 & 424.95 & 151.7 \\
\hline $\mathrm{CV}(\%)$ & - & 8.2 & 7.14 & 9.02 \\
\hline * and ${ }^{\text {ns: }}$ significant at $5 \%$ and non-significant, respectively, by the F test.
\end{tabular}


of $240 \mathrm{~g} \mathrm{ha}^{-1}$ of picloram, and observed that there was a recovery in the photosynthetic apparatus of the common bean bioindicator (Phaseolus vulgaris) after 240 days of Urochloa brizantha cultivation.

At 25 and 50 DAS, visual evaluations of intoxication were carried out using a percentage score scale ranging from 0 to 100 , where 0 implies in the absence of any injuries and 100 the plant death (ALAM 1974). This showed an increase in combined herbicide doses and high intoxication of common bean plants, even after phytoremediation with brachiaria, in soils contaminated with picloram. Among the periods evaluated, $100 \%$ intoxication rates were observed when picloran was applied at $120 \mathrm{~g} \mathrm{ha}^{-1}$ (Figure 2b). Santos at al. (2006), who evaluated the persistence of picloram in the soil to control some weed plants in pasture, using cucumber as a test plant, revealed a high intoxication in the biological indicator at 180 DAA. However, Carmo et al. (2008b) observed satisfactory results on the intoxication percentage of tomato as a bioindicator plant, when soil was cultivated for 60 days with finger millet (Eleusine coracana), at $80 \mathrm{~g} \mathrm{ha}^{-1}$ and $160 \mathrm{~g} \mathrm{ha}^{-1}$ of picloram.

A reduction tendency on maximum quantum yield of PSII $\left(\mathrm{F}_{\mathrm{v}} / \mathrm{F}_{\mathrm{m}}\right)$ was observed. However, these values were less than 0.75 only for the $60 \mathrm{~g} \mathrm{ha}^{-1}$ and $120 \mathrm{~g} \mathrm{ha}^{-1}$ doses of picloram (Figure 2c). BolhàrNordenkampf et al. (1989) reported that the maximum quantum yield could range from 0.75 to 0.85 , in plants not submitted to stress. Thus, the reduction in the ratio is an excellent indicator for the photoinhibitor effect, when plants are subjected to chemical stress (Araus \& Hogan 1994). Therefore, it can be concluded that plants exposed to $30 \mathrm{~g} \mathrm{ha}^{-1}$, $60 \mathrm{~g} \mathrm{ha}^{-1}$ and $120 \mathrm{~g} \mathrm{ha}^{-1}$ of picloram were injured, with the maximum stress being observed for $120 \mathrm{~g} \mathrm{ha}^{-1}$ of herbicide.

The analysis of relative electron transport rate (ETR) can also evaluate the tendency of linear
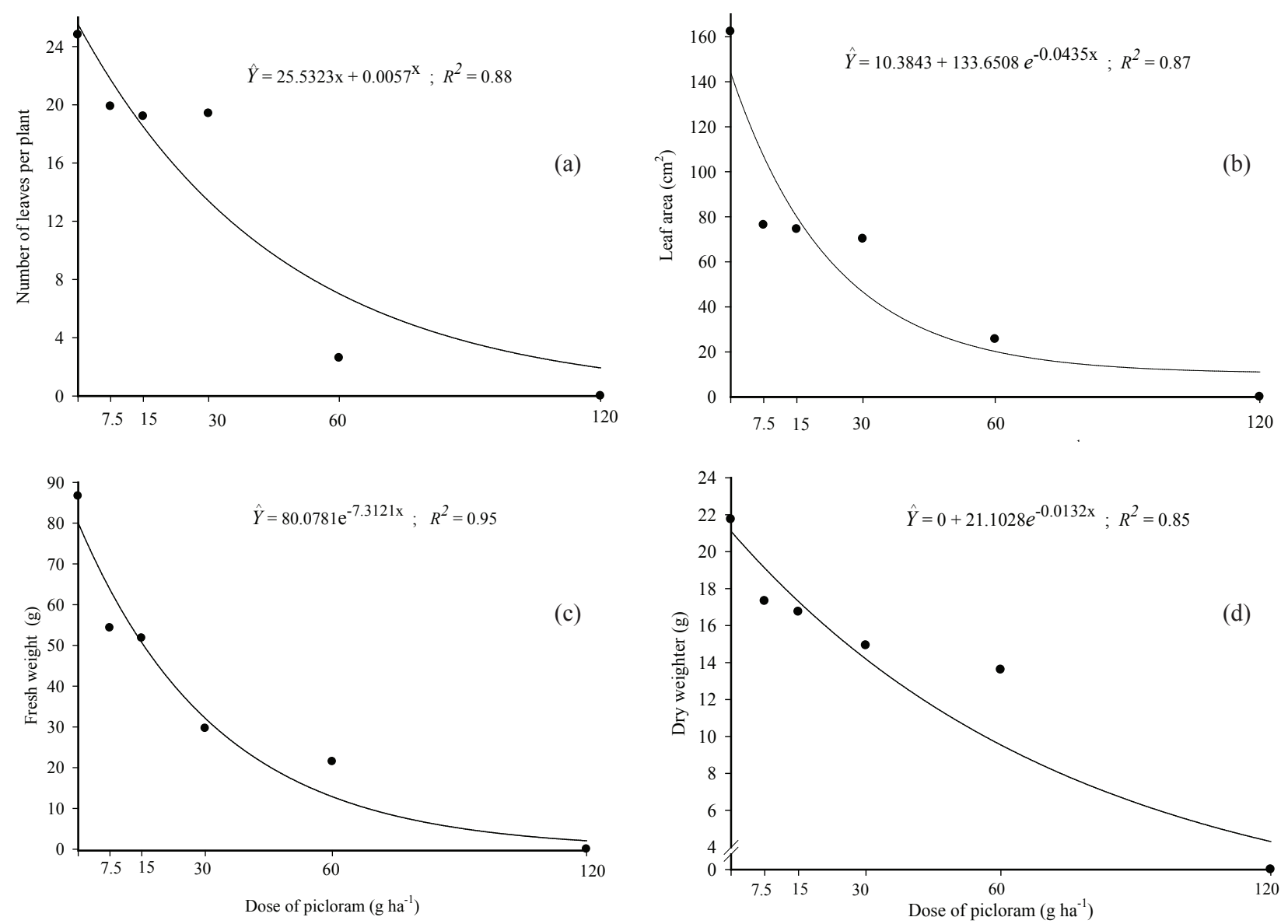

Figure 1. Number of leaves (a), leaf area (b), fresh weight (c) and dry weight (d) of common bean plants cultivated after Urochloa brizantha, in a soil treated with different doses of picloram. 

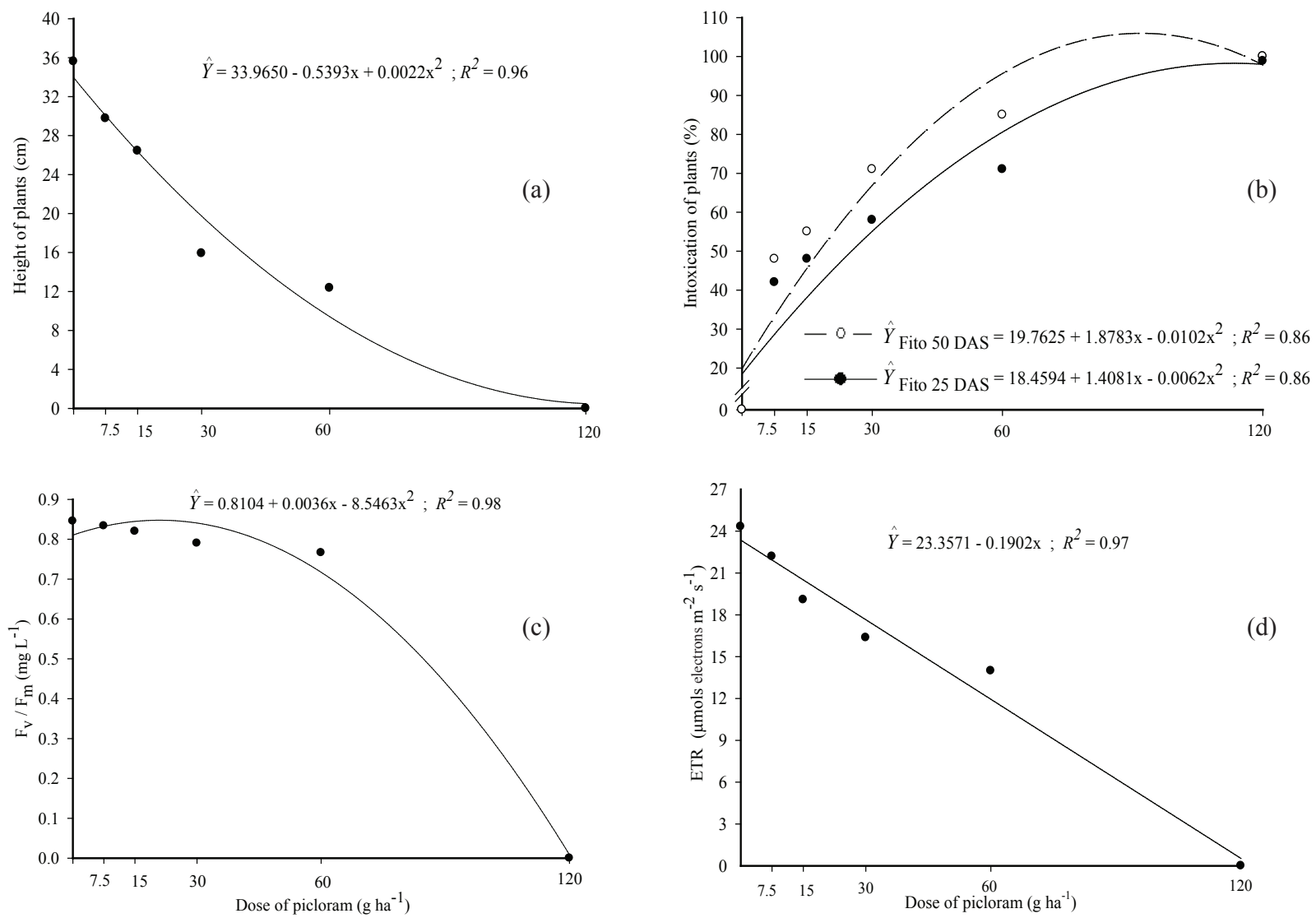

Figure 2. Height (a), intoxication (b) measured at 25 e 50 days after cultivation, maximum quantum yield PSII (c) and relative rate of electron transport (ETR) (d) of common bean plants cultivated after Urochloa brizanhta on soil treated with different doses of picloram.

reduction of this variable, when there is an increase in the herbicide dose (Figure 2d).

The ETR showed effect of the herbicide at the concentration of 0.5 micromoles $\mathrm{dm}^{-3}$, in contrast with the measurement of $\mathrm{Fv} / \mathrm{Fm}$, which was affected by the herbicide only at a concentration 100 times higher (Korres et al. 2003, Abbaspoor et al. 2006). It is suggested that auxinic herbicides, such as picloram, interfere with the action of RNA-polymerase, what consequently affects the synthesis of nucleic acid and proteins (Thill 2003), and also seriously affects the cell appearance plasticity (Silva et al. 2007). In addition, these herbicides induce intense cellular proliferation, besides interrupting the phloem (Silva et al. 2007). Cellular enlargement is also observed and may be related with the reduction of the cell osmotic potential induced by the effect of these herbicides over loosening of cell walls. Probably, the increase in herbicide doses disturbed the photosynthetic activity of the common bean plants, what indirectly changed the photosystem, reducing the growth rate.
The soil comparison before and after the experiment showed a $\mathrm{pH}$ (average of 6.0) higher than the pKa (2.3) of the herbicide, revealing a higher dissociation of the herbicide in the soil. In addition, the soil had brachiaria residues with herbicide incorporated. These two facts could result in a high concentration of picloram retained in the soil colloids, which also increased its absorption by the bioindicator plants.

According to Rodrigues et al. (2005), picloram presents a pKa of 2.3. The higher the pKa of herbicides, the lower it is its acidic character and its capacity to be found in ionic form. Therefore, when the soil $\mathrm{pH}$ becomes closer, in relation to the $\mathrm{pKa}$ of the herbicide, the chances of its availability in its neutral form are increased, what also increases its absorption in the particles of soil colloid sand, causing high availability of the herbicide in the environment (Silva et al. 2007).

D'Antonino et al. (2009) reported a high leaching potential of picloram on three soil types 
with different pH (Red-Yellow Ultisol - pH 5.9; RedYellow Latossol - pH 4.1; Red-Yellow Latosol - $\mathrm{pH}$ 4.9). However, the soil characteristics analyzed made possible to conclude that the leaching index and dissociation were not influenced by the $\mathrm{pH}$, when the soil organic matter level was high.

\section{CONCLUSIONS}

1. The phytoremediation of a Red-Yellow Ultisol contaminated with picloram, using Urochloa brizantha (Piatã cultivar) at 150 days after planting, is effective only for lower doses of the herbicide applied. Under the conditions of this study, the result is not satisfactory with doses of picloram higher than $30 \mathrm{~g} \mathrm{ha}^{-1}$.

2. Phaseolus vulgaris has a good potential as a biological indicator for the presence of lower doses of picloram residues in the soil.

3 . The visual intoxication and relative electron transport rates are excellent morphological and physiological parameters to indicate the presence of picloram in the soil.

\section{ACKNOWLEDGEMENTS}

The authors would like to thank the Fundação de Amparo à Pesquisa do Estado de Minas Gerais (Fapemig), for the financial support, and the Coordenação de Aperfeiçoamento de Pessoal de Nível Superior (Capes), for the research grant provided to the first author.

\section{REFERENCES}

ABBASPOOR, M. et al. The effect of root-absorbed PSII inhibitors on Kautsky curve parameters in sugar beet. Weed Research, v. 46, n. 3, p. 226-235, 2006.

ALBUQUERQUE, M. A. et al. Mineralização e sorção de atrazina em Latossolo Roxo sob cultivo convencional e plantio direto. Revista Brasileira de Ciencia do Solo, v. 25, n. 1, p. 179-188, 2001.

ARAUS, J. L.; HOGAN, K. P. Comparative leaf structure and patterns of photoinhibition of the neotropical palms Scheelea zonensis and Socratea durissima growing in clearing and forest understory during the dry season in Panama. American Journal of Botany, v. 81, n. 6, p. 726-738, 1994.

ASÓCIACION LATINOAMERICANA DE MALEZAS (ALAM). Recomendaciones sobre unificación de los sistemas de avaluacion en ensayos de control de malezas. Bogotá: ALAM, 1974.
BELO, A. F. et al. Efeito da umidade do solo sobre a capacidade de Canavalia ensiformis e Stizolobium aterrimum em remediar solos contaminados com herbicidas. Planta Daninha, v. 25, n. 2, p. 239-249, 2007 a.

BELO, A. F. et al. Fitorremediação de solo adubado com composto orgânico e contaminado com trifloxysulfuronsodium. Planta Daninha, v. 25, n. 2, p. 251-258, 2007 b.

BERISFORD, Y. C. et al. Leaching and persistence of herbicides for kudzu (Pueraria montana) control on pine regeneration. Weed Science, v. 54, n. 2, p. 391-400, 2006.

BOLHÀR-NORDENKAMPF, H. R. G. et al. Chlorophyll fluorescence as probe of the photosynthetic competence of leaves in the field: a review of current instrument. Functional Ecology, v. 3, n. 4, p. 497-514, 1989.

BRASIL. Ministério da Agricultura, Pecuária e Abastecimento. Coordenação Geral de Agrotóxicos e Afins. Agrofit. 2013. Available at: <http://agrofit. agricultura.gov.br/agrofit_cons/principal_agrofit_cons>. Acess on: April 1, 2016.

CANTARUTTI, R. B. et al. Pastagens. In: RIBEIRO, A. C.; Guimarães, P. T. G.; AlVAREZ, V. H. Recomendações para o uso de corretivos e fertilizantes em Minas Gerais: $5^{\text {a }}$ aproximação. Viçosa: Comissão de Fertilidade do Solo do Estado de Minas Gerais, 1999. p. 332-339.

CARMO, M. L. et al. Influência do período de cultivo de Panicum maximum (cultivar Tanzânia) na fitorremediação de solo contaminado com picloram. Planta Daninha, v. 26, n. 2, p. 315-322, 2008 a.

CARMO, M. L. et al. Influência do período de cultivo do capim-pé-de-galinha-gigante (Eleusine coracana) na fitorremediação de solo contaminado com picloram. Planta Daninha, v. 26, n. 3, p. 601-609, 2008 b.

CELIS, R. et al. Sorption and leaching behaviour of polar aromatic acids in agricultural soils by batch and column leaching tests. European Journal of Soil Science, v. 56, n. 3, p. 287-297, 2005.

COSTA, M. A.; MONTEIRO, R. T. R.; TORNISIELO, V. L. Degradação de ametrina em areia quartzosa com adição de solo rizosférico de cana-de-açúcar. Revista Brasileira de Ciência do Solo, v. 24, n. 1, p. 43-48, 2000.

CUNNINGHAM, S. D. et al. Phytoremediation of soils contaminated with organic pollutants. Advances of Agronomy, v. 56, n. 1, p. 55-114, 1996.

D’ANTONINO, L. et al. Crescimento de plantas de café em solos com resíduos de picloram. Planta Daninha, v. 30, n. 1, p. 193-200, 2012.

D'ANTONINO, L. et al. Efeitos de culturas na persistência de herbicidas auxínicos no solo. Planta Daninha, v. 27, n. 2, p. 371-378, 2009. 
DEUBERT, K. H.; CORTE-REAL, I. Soil residues of picloram and triclopyr after selective foliar application on utility rights-of-way. Journal of Arboriculture, v. 12, n. 11, p. 269-272, 1986.

FERREIRA, O. G. L. et al. DDA: software para determinação de área foliar, índice de área foliar e área de olho de lombo. Versão 1.2. Santo Augusto: IFFarroupilha, 2008.

FRANCO, M. H. R. et al. Fitorremediação de solos contaminados com picloram por Urochloa brizantha. Pesquisa Agropecuária Tropical, v. 44, n. 4, p. 460-467, 2014.

KORRES, N. E. et al. Chlorophyll fluorescence technique as a rapid diagnostic test of the effects of the photosynthetic inhibitor chlortoluron on two winter wheat cultivars. Annals of Applied Biology, v. 143, n. 1, p. 53-56, 2003.

KRAUSE, G. H.; WEIS, E. Chlorophyll fluorescence and photosynthesis: the basics. Annual Review of Plant Physiology and Plant Molecular Biology, v. 42, n. 1, p. 313-349, 1991.

PIRES, F. R. et al. Seleção de plantas com potencial para fitorremediação de tebuthiuron. Planta Daninha, v. 21, n. 3, p. 451-458, 2003.

PIRES, F. R. et al. Avaliação da fitorremediação de tebuthiuron utilizando Crotalaria juncea como planta indicadora. Revista Ciência Agronômica, v. 39, n. 2, p. 245-250, 2008.

PROCÓPIO, S. de O. et al. Fitorremediação de solo contaminado com picloram por capim-pé-de-galinhagigante (Eleusine coracana). Revista Brasileira de Ciência do Solo, v. 32, n. 6, p. 2517-2524, 2008.

ROCHA, W. S. D. et al. Influência do pH na sorção de imazaquin em um Latossolo Vermelho acriférrico. Revista Brasileira de Ciência do Solo, v. 24, n. 3, p. 649-655, 2000.

RODRIGUES, B. N.; ALMEIDA, F. S. Guia de herbicidas. 5. ed. Londrina: Ed. dos Autores, 2005.
SANTOS, D. P. et al. Determinação de espécies bioindicadoras de resíduos de herbicidas auxínicos. Revista Ceres, v. 60, n. 3, p. 354-362, 2013.

SANTOS, E. A. et al. Fitoestimulação por Stizolobium aterrimum como processo de remediação de solo contaminado com trifloxysulfuron-sodium. Planta Daninha, v. 25, n. 2, p. 259-265, 2007 a.

SANTOS, J. B. et al. Fitorremediação de áreas contaminadas por herbicidas. In: SILVA, A. A.; SILVA, J. F. Tópicos em manejo de plantas daninhas. Viçosa: Ed. UFV, 2007b. p. 249-278.

SANTOS, L. B. O. et al. Determination of picloram in waters by sequential injection chromatography with UV detection. Journal of the Brazilian Chemical Society, v. 21, n. 8, p. 1557-1562, 2010.

SANTOS, M. V. et al. Eficácia e persistência no solo de herbicidas utilizados em pastagem. Planta Daninha, v. 24, n. 2, p. 391-398, 2006.

SILVA, A. A. et al. Herbicidas: classificação e mecanismo de ação. In: SILVA, A. A.; SILVA, J. F. (Eds.). Tópicos em manejo de plantas daninhas. Viçosa: Ed. UFV, 2007. p. 83-148.

SINDICATO NACIONAL DA INDÚSTRIA DE PRODUTOS PARA DEFESA AGRÍCOLA (SINDAG). Dados 2009. 2009. Available at: <http://www.sindag.com. br>. Acess on: Aug. 23, 2015.

THILL, D. Growth regulator herbicides. In: WELLER, S. C. et al. (Eds.). Herbicide action course. West Lafayette: Purdue University, 2003. p. 267-291.

WYK, L. J. V.; REINHRDT, C. F. A bioassay technique detects imazethapyr leaching and liming-pendent activity. Weed Science, v. 15, n. 3, p. 1-6, 2001. 